\title{
Pyramidalized Double Bonds Containing Endoperoxide Linkages: Photooxygenation of Dimethyl cis-3,8-Dihydroheptalene-3,8-dicarboxylate
}

\author{
Nurullah Saraçoǧlu, ${ }^{\dagger}$ Abdullah Menzek, ${ }^{\dagger}$ Şafak Sayan,‡ Ulrike Salzner,*,‡ and Metin Balci*,\$ \\ Departments of Chemistry, Atatürk University, 25240 Erzurum, Turkey, Bilkent University, \\ 06533 Ankara, Turkey, and Middle East Technical University, 06531 Ankara, Turkey
}

Received March 4, 1999

\begin{abstract}
Diels-Alder cycloaddition utilizing singlet oxygen as the dienophile with dimethyl cis-3,8dihydroheptalene-3,8-dicarboxylate (5) has been investigated, and monoaddition product 7 has been isolated. The addition of a second singlet oxygen to the cycloheptatriene unit in 7 gave syn-bis(norcaradiene) bis(endoperoxide) 4. ${ }^{1} \mathrm{H}$ NMR spectral studies and theoretical calculations indicate the increased pyramidalization in syn-4 compared with carbon analogue. The increased pyramidalization results from hyperconjugation between the central $\pi$-bond and the four adjacent $\mathrm{C}-\mathrm{O}$ bonds and by rehybridization at C3, C4, C5, and C6. Furthermore, the increased reactivity for syn-4, which is probably arising from further folding of the central double bond, is al so in agreement with theoretical calculations.
\end{abstract}

\section{Introduction}

Chemists continue to be fascinated by the imposition of stress and strain upon organic molecules. The strained ring systems are unusually reactive and often unstable. ${ }^{1}$ Theoretical work has shown that a trigonal center of a double bond pyramidalizes when located in an unsymmetrical environment. ${ }^{2}$ When there is an unsymmetrical arrangement of allylic bonds with respect to an alkene, there is a driving force for pyramidalization ${ }^{3}$ in order to achieve partial staggering of the alkene with respect to the allylic bonds. Furthermore, Houk has postulated that the electron density of the alkenyl $\pi$-bond influences the degree of the pyramidalization. In 1980, syn- and antisesquinorbornene were synthesized independently by Bartlett ${ }^{4}$ and Paquette. ${ }^{5} \mathrm{X}$-ray studies ${ }^{6}$ showed that the $\pi$-bonded carbons in the syn isomer are significantly pyramidalized, with folding angles ranging from 16 to $18^{\circ}$.

Reaction of the pyramidalized double bonds with a variety of reagents results in addition to the exo face of the double bond. ${ }^{7}$ The observed stereochemistry is certainly not surprising, since both electronic and steric

\footnotetext{
† Atatürk University.

‡ Bilkent University.

$\S$ Middle East Technical University.

(1) (a) Marchand, A. P. Chem. Rev. 1989, 89, 1011-1033. (b) Klunder, A. J . H. Chem. Rev. 1989, 89, 1035-1050. (c) Paquette, L. A. Chem. Rev. 1989, 89, 1051-1065. (d) Warner, P. M. Chem. Rev. 1989 89, 1067-1093. (e) J ohnson, R. P. Chem. Rev. 1989, 89, 1111-1124. (f) Halton, B. Chem. Rev. 1989, 89, 1095-1109.

(2) (a) Wipf, G.; Morokuma, K. Tetrahedron Lett. 1980, 21, 4445 (b) Paddon-Row, M. N.; Randan, N. G.; Houk, K. N. J . Am. Chem. Soc. 1982, 104, 7162. (c) Hake, H.; Landen, H.; Martin, H.-D.; Spellmeyer, D. C. Tetrahedron Lett. 1989, 29, 6601.

(3) F or a review of pyramidalized double bonds, see: Borden, W. T. Chem. Rev. 1989, 89, 1095.

(4) Bartlett, P. D.; Blakeney, A. J .; Kimura, M.; Watson, W. H. J . Am. Chem. Soc. 1980, 102, 1383.

(5) Paquette, L. A.; Car, R. V. C.; Böhm, M. C.; Gleiter, R. J . Am. Chem. Soc. 1980, 102, 1186, 7218.

(6) (a) Hagenbuch, J .-P.; Vogel, P.; Pinkerton, A. A.; Schwarzenbach, D. Helv. Chim. Acta 1981, 64, 1819. (b) Paquette, L. A.; Schaefer, A G.; Blount, J . F. J . Am. Chem. Soc. 1983, 105, 2095. (c) Paquette, L. A.; Kunzer, H.; Green, K. E.; De Lucchi, O.; Dicini, G.; Pasquato, L.; Valle, G. J . Am. Chem. Soc. 1986, 108, 3453.
}

factors would be expected to favor attack on the convex face of the pyramidalized double bond.

In recent years, we have been concerned with the synthesis, structure analysis, and chemical properties of pyramidalized al kenes and have reported the synthesis of syn- and anti-1-38 (Chart 1). It has been found that, in asymmetric environments, double bonds tend to pyramidalize slightly in order to mi nimize edlipsing interactions. The results of X-ray analysis showed that compounds in syn structures are pyramidalized and that the relevant pyramidalization angl e varies between 16.4 and $19.9^{\circ}$, while anti isomers have a planar structure.

The syn and anti structures 1-3, resulting from the addition of such dienophiles as benzyne or dimethyl acetylenedicarboxylate to dimethyl cis- and trans-3,8dihydroheptalene-3,8-dicarboxylate (5), are stable. The strong carbon-carbon bond linkages in 1-3 can tolerate the strain energies inherent in these molecules. To test the stability and reactivity of a compound where the $\mathrm{C}-\mathrm{C}$ linkages in $\mathbf{1}-\mathbf{3}$ are replaced by $-\mathrm{O}-\mathrm{O}-$ functional groups, we have undertaken the synthesis of syn-4. In this regard, we studied the cycloaddition reactions of cisheptalene $\mathbf{5}$ with singlet oxygen.
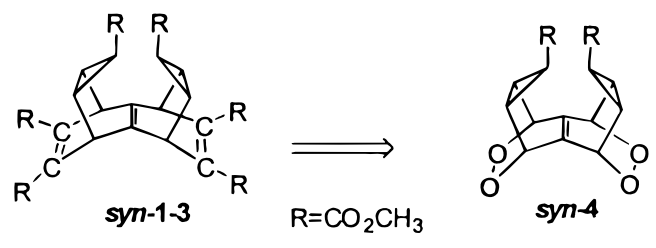

(7) Bartlett, P. D.; Blakeney, A. J .; Combs, G. L.; Galloy, J .; Roof, A. A. M.; Subramanyam, R.; Watson, W. H.; Winter, W. J .; Wu, C. In Stereochemistry and Reactivity of Systems Containing $\pi$ Electrons; Watson, W. H., Ed.; Verlag Chemie International: Deerfield Beach, $\mathrm{FL}, 1983 ; \mathrm{p} 75$.

(8) (a) Menzek, A.; Krawiec, M.; Watson W. H.; Balci, M. J . Org. Chem. 1991, 56, 6755. (b) Menzek, M.; Balci, M. Aust. J . Chem. 1993, 46, 1613. (c) Menzek, A.; Saracoglu, N.; Balci, M.; Watson, W. H.; Krawiec, M. J . Org. Chem. 1995, 60, 829. (d) Balci, M.; Bourne, S. A.; Menzek, A.; Saraçoglu, N.; Watson, W. H. J . Chem. Crystallogr. 1995, 25, 107. 
Chart 1

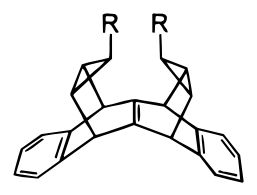

syn-1
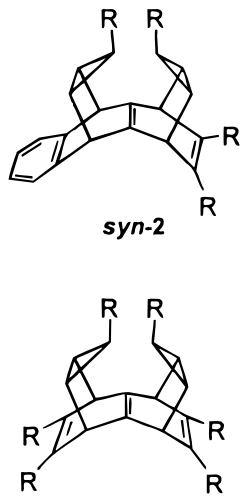

syn-3

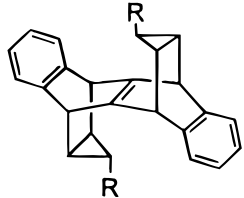

anti-1

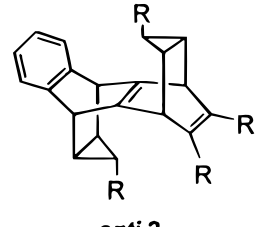

anti-2

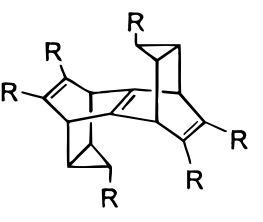

anti-3
$\mathrm{R}=\mathrm{CO}_{2} \mathrm{CH}_{3}$

\section{Results and Discussion}

Dimethyl cis-3,8-dihydroheptalene-3,8-dicarboxylate (5) was synthesized previously as reported by us. ${ }^{8 c}$ It has been shown that singlet oxygen adds to 7-substituted cycloheptatriene derivatives to form bicyclic endoperoxides, whose structures (cycloheptatriene or norcaradiene) vary with the nature of the substituents. ${ }^{9}$ The equilibrium for the symmetry-allowed valence isomerization of cycloheptatriene and norcaradiene has been demonstrated..$^{10}$ Electron-accepting substituents, such as - $\mathrm{CHO}$, $-\mathrm{COOR}$, and $-\mathrm{CN}$ at $\mathrm{C}-7$, tend to shift the equilibrium to the norcaradiene side, while el ectron-donating substituents favor the cycloheptatriene structure.

The photooxygenation of $\mathbf{5}$ was carried out in $\mathrm{CCl}_{4}$ in the presence of tetraphenylporphyrine (TPP) as sensitizer. To isol ate the monoaddition product, the reaction was stopped after $2 \mathrm{~h}$. The norcaradiene endoperoxide 7 was isolated in $27 \%$ yield after crystallization from $\mathrm{CHCl}_{3} /$ ether following flash chromatography over florisil (Scheme 1). The $200 \mathrm{MHz}{ }^{1} \mathrm{H}$ and $50 \mathrm{MHz}{ }^{13} \mathrm{C} \mathrm{NMR}$ spectra of endoperoxide 7 completely support the proposed structure, with 11 signals in the ${ }^{13} \mathrm{C}$ NMR spectrum being in perfect agreement with the symmetry of the molecule.

Next, we turned our attention to the chemical reactions of $\mathbf{7}$ and studied COTPP-catalyzed rearrangement of this endoperoxide 7. We have previously applied this reaction to unsaturated bicyclic endoperoxides with strained and perturbed diene moieties and found that the CoTPP. catalyzed reaction suppresses certain side reactions such as the formation of epoxy ketones. ${ }^{11}$ To our surprise,

(9) (a) Adam, W.; Balci, M. J. Am. Chem. Soc. 1979, 101, 7537. (b) Adam, W.; Balci, M.; Pietrzak, M. J. Am. Chem. Soc. 1979, 101, 6285 (c) Şengül. M. E.; Ceylan, Z.; Balci, M. Tetrahedron 1997, 53, 85228532. (d) Şengül, M. E.; Balci, M. J . Chem. Soc., Perkin Trans. 1 1997, 2071-2077.

(10) For a most recent review on the cycloheptatriene-norcaradiene equilibrium, see: Balci, M. Turk. J. Chem. 1992, 16, 42.

(11) (a) Balci, M.; Sütbeyaz, Y. Tetrahedron Lett. 1983, 24, 311. (b) Sütbeyaz, Y.; Seçen, H.; Balci, M. J . Org. Chem. 1988, 53, 2312.
Scheme 1<smiles>[R]C1C=CC2=C(C=C1)C=CC([R])C=C2</smiles>

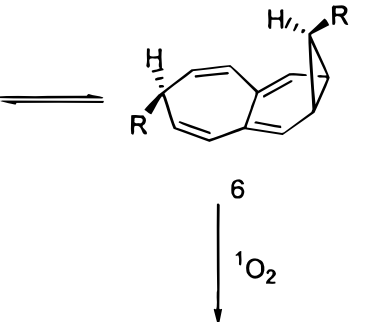

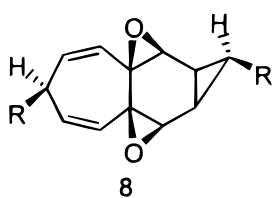

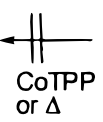

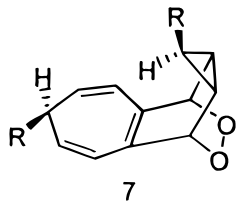<smiles>CCCCC(C)C</smiles><smiles>[R]C1C=CC2=C(C=C1)C(O)C1C([R])C1C2=O</smiles>

9

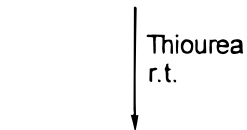<smiles>[R]C1C=CC2=C3C([R])C(O)C3C(O)C2C1[R]</smiles>

thermolysis and CoTPP-catalyzed reaction of endoperoxide 7 resulted in the formation of polymeric materials instead of the expected diepoxide $\mathbf{8}$. Furthermore, basecatalyzed rearrangement ${ }^{12}$ with $\mathrm{NE}_{3}$ al so gave polymeric materials and did not produce the desired hydroxy ketone 9.

However, one isolable product derived from 7 was formed upon reduction of the peroxide linkage by thiourea. It is well established ${ }^{12}$ that thiourea reduces only the oxygen-oxygen bond where other functionalities in the molecule remain unchanged. The reaction of $\mathbf{7}$ with thiourea in methanol gave diol $\mathbf{1 0}$ (Scheme 1). The ${ }^{1} \mathrm{H}$ and ${ }^{13} \mathrm{C}$ NMR spectra of $\mathbf{1 0}$ confirmed the expected symmetrical structure. IR analysis also indicated the presence of hydroxyl groups. We then investigated the oxidation of diol $\mathbf{1 0}$ with $\mathrm{MnO}_{2}$. Diketone $\mathbf{1 2}$ was the expected product in this reaction, which can be formed by oxidation of allylic diol $\mathbf{1 0}$. However, the elemental analysis of the isolated product confirmed a molecular formula of $\mathrm{C}_{15} \mathrm{H}_{12} \mathrm{O}_{6}$, which corresponds to the ringcontracted product 11 . The ${ }^{1} \mathrm{H}$ and ${ }^{13} \mathrm{C}$ NMR spectra both support the proposed structure.

For this unusual conversion of $\mathbf{1 0}$ to $\mathbf{1 1}$, we propose the mechanism depicted in Scheme 2. First, an allylic oxidation takes place to form $\mathbf{1 2}$. Then an intramolecular hydrogen shift in the cycl oheptatriene unit of $\mathbf{1 2}$ followed by oxidation of the double allylic methylene protons in the seven-membered ring will furnish the tropone derivative 14. In the final step, the decarbonylation of tropone will afford homonaphthoquinone derivative $\mathbf{1 1}$ (Scheme 2). It is well-known from the literature ${ }^{13}$ that cycloheptatriene can easily form benzene derivatives by losing the methylene group upon undergoing oxidation reactions.

(12) Balci, M. Chem. Rev. 1981, 81, 91

(13) (a) Adam, W.; Balci, M. J . Am. Chem. Soc. 1979, 101, 7537. (b) Atasoy, B.; Balci, M. Tetrahedron 1986, 42, 1461. (c) Akbulut, N.; Menzek, A.; Balci, M. Tetrahedron Lett. 1987, 28, 1689. (d) Akbulut, N.; Menzek, A.; Balci, M. Turk. J . Chem. 1991, 15, 232. 
Scheme 2

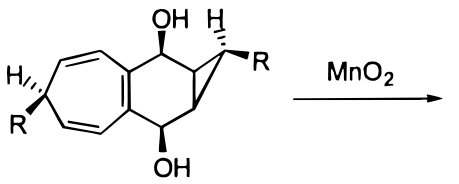

10<smiles>[R]C1C=CC2=C(C=C1)C(=O)C1C([R])C1C2=O</smiles>

12<smiles>[R]C1=CCC2=C(C=C1)C(=O)C1C([R])C1C2=O</smiles>

13<smiles>[R]c1ccc2c(c1)C(=O)C1C([R])C1C2=O</smiles>

11<smiles>[R]C(=O)OC</smiles>

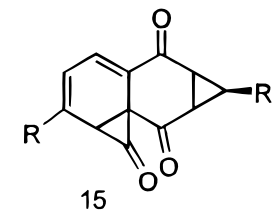<smiles>C=C</smiles><smiles>[R]c1ccc2c(c1)C(=O)C1C([R])C1C2=O</smiles>

14
Construction of the syn-4 framework was achieved upon successful addition of $2 \mathrm{~mol}$ of singlet oxygen to $\mathbf{5}$ during prolonged photooxygenation under the previously given reaction conditions. Bis(endoperoxide) syn-4 was isolated in $20 \%$ yield (after crystallization). The ${ }^{1} \mathrm{H}$ and ${ }^{13} \mathrm{C}$ NMR spectra of $\mathbf{s y n}-\mathbf{4}$ confirmed a symmetrical molecule (F igure 1). All efforts to obtain suitable crystals of syn-4 for an X-ray analysis were failed.

The ${ }^{1 H}$ NMR spectrum of syn-4 consists of four groups of signals, which are assigned to bridgehead (endoperoxide), methoxyl, cyclopropane, and cyclopropyl (adjacent to the ester group). The ${ }^{13} \mathrm{C}$ NMR spectrum of $\mathbf{s y n}-\mathbf{4}$ exhibits 6 lines in accordance with the proposed structure. The ${ }^{1} \mathrm{H}$ NMR spectrum of syn-4 is very similar to that of syn-3. The position of the cyclopropyl proton where the carbomethoxyl group is attached is very informative in view of the steric effects.

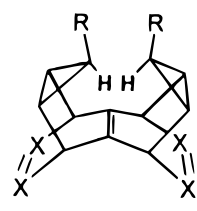

syn

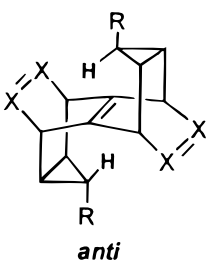

anti
Comparison of the ${ }^{1} \mathrm{H}$ NMR spectra of syn-1 with anti-1 indicates that the cyclopropane proton resonance in syn-1 is shifted remarkably downfield (2.68 ppm) (Figure 1). In contrast, the cyclopropyl proton in anti-1 resonates at $0.3 \mathrm{ppm}$. The high-field resonance of this proton $(0.3 \mathrm{ppm})$ can be accounted by the location of the cyclopropyl proton in the shielding cone of the central double bond. ${ }^{14}$ However, we attribute the extraordinary shift of cyclopropyl proton (which is also located over the double bond) in syn-1 to steric compression between these internal cyclopropyl protons. It is well-known that inter-

(14) Adam, W.; Balci, M. J . Org. Chem. 1979, 44, 1189. actions related to the van der Waals effect cause a paramagnetic contribution to the shielding constants which results in a shift to lower field. ${ }^{15}$ In the compounds syn-1-3, the cyclopropyl protons resonate in the region of 2.5-2.68 ppm (Table 1). On the other hand, the measured pyramidalization angle in syn-1-3 was found to vary between 16.4 and $19.9^{\circ}$. Therefore, we see a correlation between the chemical shift and the degree of the pyramidalization angle in these compounds. However, the internal cyclopropyl protons in syn-4 resonate at $1.44 \mathrm{ppm}$. This is a remarkable upfield shift compared to those of syn-1-3. This upfield shift can be ascribed to partial relief of the proton-proton repulsion in syn-4. Inductive effect of the oxygen atoms in the peroxide linkages cannot be responsible for this shift, since oxygen atoms can cause a change in the chemical shift to lower field and not to higher field. We assume, then, on the basis of the chemical shift of the internal cyclopropyl protons in syn-4 that the central double bond in syn-4 should be more pyramidalized than in syn-1-3.

Increased reactivity of the bis(endoperoxide) syn-4 could be observed by its facile rearrangement to the corresponding bis(epoxide) $\mathbf{1 6}$ in nearly quantitative yield upon standing at room temperature (Scheme 3). Norcaradiene endoperoxides are usually quite stable at room temperature. One of the common reactions of unsaturated [n.2.2] bicyclic endoperoxides is cleavage of the weak oxygen-oxygen bond followed by addition of the oxygen radicals to the adjacent double bond to give the corresponding bis(epoxides) with the syn-configuration. This increased reactivity also supports the higher degree of pyramidalization.

To compare the effect of the two different bridging systems (oxygen-oxygen and carbon-carbon), we have synthesized the compound $\mathbf{1 8 .}$

We recently reported ${ }^{8 c}$ the synthesis of $\mathbf{1 7}$ by addition of p-benzoquinone to cis-heptalene derivative 5. The reaction of $\mathbf{1 7}$ with singlet oxygen gave syn-endoperoxide 18 as the sole product. The structural assignment was made from the NMR data. Cyclopropyl protons (CHCOOR) are resonating at $1.31-1.78$ ppm, respectively. These values are between those of $\mathbf{4}$ and syn-1-3. On the basis of these values, we propose that the folding of the central double bond in $\mathbf{1 7}$ is higher than in syn-1-3 but less than found in syn-4. This compound also rearranged at room temperature (Scheme 4). The disappearance of the olefinic resonances in the ${ }^{13} \mathrm{C}$ spectrum indicated the formation of the expected bis(epoxide) $\mathbf{1 8}$ in quantitative yield.

\section{Theoretical Calculations}

Models for syn-3 and syn-4 (Figure 2) were obtained by replacing the ester groups with hydrogens $(R=H)$. Geometries of syn-3 and syn-4 were optimized in $\mathrm{C}_{2 \mathrm{v}}$ symmetry by employing Becke's three parameter hybrid functional ${ }^{16}$ and the $6-31 G^{* 17}$ basis set. The calculations were carried out with Gaussian $94 .{ }^{18}$ Electronic struc-

(15) (a) Tori, K., Ueyama, M., Tsuji, T.; Matsamura, H.; Tanida, H.; I wamura, H.; Kushida, K.; Nishida, T.; Satoh, S. Tetrahedron 1974, 327. (b) Gheorghiu, M. D.; Olteanu, E. J . Org. Chem. 1987, 52, 5158.

(16) Becke, A. D. J . Chem. Phys. 1993, 98, 5648.

(17) Frisch, M.J .; Frisch, A. E.; Foresman, J . B. Gaussian 94 User's Reference; Gaussian, Inc.: Pittsburgh, PA, 1994-1995. 


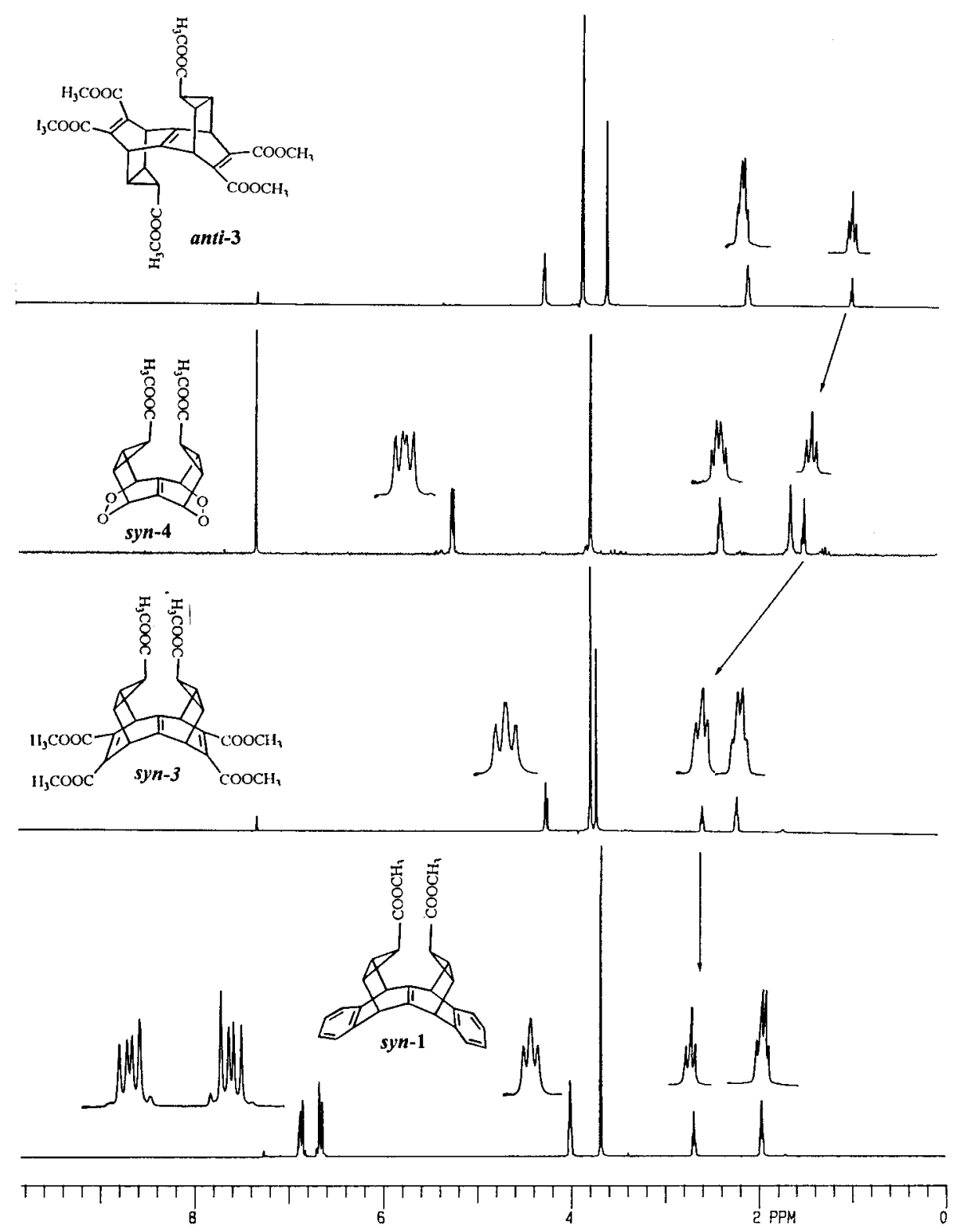

Figure 1. $200 \mathrm{MHz}^{1} \mathrm{H}$ NMR spectra of the compounds syn-1, syn-3, anti-3, and syn-4.

Table 1. Cyclopropyl (CHCOOR) Resonances of the Compounds $1-4$ and 18 in ppm

\begin{tabular}{cll}
\hline compd & syn-isomer & anti-isomer \\
\hline $\mathbf{1}$ & 2.68 & 0.28 \\
$\mathbf{2}$ & 2.60 & $0.08-1.06$ \\
$\mathbf{3}$ & 2.53 & 0.94 \\
$\mathbf{4}$ & 1.44 & \\
$\mathbf{1 8}$ & $1.78-1.31$ &
\end{tabular}

tures were analyzed with the natural bond orbital (NBO) method ${ }^{19-21}$ which is available in Gaussian 94.

In Figure 2 experimental ${ }^{8}$ and theoretical bond lengths are compared for syn-3. Bond angles are compiled in

(18) Frisch, M. J .; Trucks, G. W.; Schlegel, H. B.; Gill, P. M. W.; J ohnson, B. G.; Robb, M. A.; Cheeseman, J. R.; Keith, T.; Petersson, G. A.; Montgomery, J. A.; Raghavachari, K.; Al-Laham, M. A.; Zakrzewski, V. G.; Ortiz, J . V.; Foresman, J . B.; Peng, C. Y.; Ayala, P. Y.; Chen, W.; Wong, M. W.; Andres, J . L.; Replogle, E. S.; Gomperts, R.; Martin, R. L.; Fox, D. J.; Binkley, J . S.; Defrees, D. J .; Baker, J .; Stewart, J. P.; Head-Gordon, M.; Gonzalez, C.; Pople, J . A. Gaussian 94; Gaussian, Inc.: Pittsburgh, PA, 1995.

(19) Reed, E. A.; Weinstock, R. B.; Weinhold, F.J . Chem. Phys. 1985, 83, 735 .

(20) Reed, A. E.; Weinhold, F. J . Chem. Phys. 1985, 83, 1736.
Table 2. Theoretical bond lengths are between 0.005 and $0.017 \AA$ larger than experimental ones. Only the $C 7=C 9$ bond is calculated to be shorter compared to the experimental bond distance. This is most likely due to the absence of the ester groups, whose $\pi$-systems can interact with the $\mathrm{C} 7=\mathrm{C} 9$ bond. Bond angles are reproduced by theory with deviations of less than $1^{\circ}$. The bending angle at the central pyramidalized double bond is $3^{\circ}$ smaller in theory than in the X-ray structure. Considering that all ester groups were removed for the calculations, the agreement between theory and experiment is very good.

Peroxide syn-4 could not be crystallized. Only the theoretical geometry (Figure 1 and Table 2) and the NMR spectrum are available for structural analysis. Since the agreement between theory and experiment for the carbon compound is good, we are confident that the calculated geometry of syn-4 is reliable. Most notable are the increased pyramidality $\left(19.9^{\circ}\right.$ vs $\left.16.9^{\circ}\right)$, the increased length of the $\mathrm{C} 1=\mathrm{C} 2$ bond $(1.345 \AA$ vs $1.339 \AA)$, and the

(21) Reed, E. A.; Curtiss, L. A.; Weinhold, F. Chem. Rev. 1988, 88, 


\section{Scheme 3}<smiles>[R]C1C=CC2=C(C=C1)C=CC([R])C=C2</smiles>

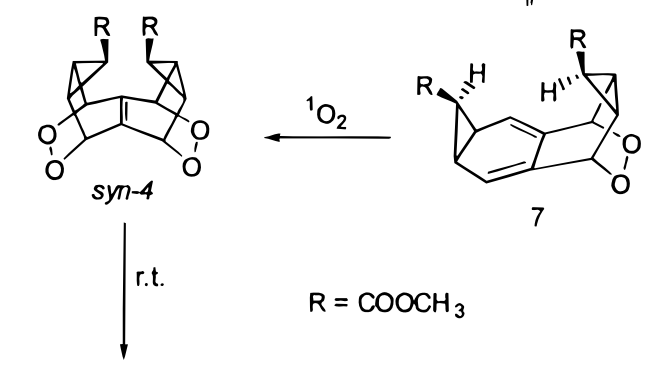

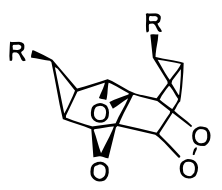

16

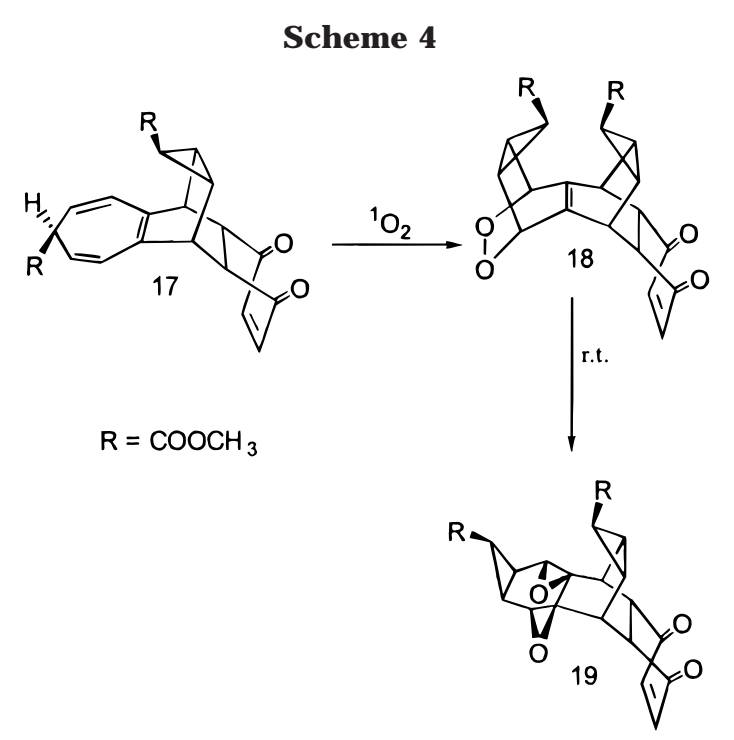

larger distance between the nonbonded cyclopropane hydrogens (2.062 $\AA$ vs $1.813 \AA$ ) in syn-4 as compared to syn-3. Thus, theoretical calculations fully confirm conclusions based on the different chemical shifts of the cyclopropane protons in the NMR-spectra of syn-3 and syn-4. F urther differences between syn-3 and syn-4 arise for the $\mathrm{C} 1-\mathrm{C} 3, \mathrm{C} 3-\mathrm{C} 11$, and $\mathrm{C} 11-\mathrm{C} 13$ bond distances. In syn-4 the former two are shortened by 0.017 and 0.039 $\AA$; the latter is lengthened by $0.017 \AA$. Changes in bond angles are rather subtle with maximum differences of $3.3^{\circ}$ between syn-3 and syn-4.

In principle, three factors could be responsible for the observed geometrical differences between syn-3 and syn4. First, the longer $\mathrm{O} 7-\mathrm{O} 9$ bond as compared to $\mathrm{C} 7=\mathrm{C} 9$ allows for some relieve of steric strain and could account for the increased distance between the cyclopropane hydrogens. This, however, would reduce the strain on the double bond and decrease rather than increase bending
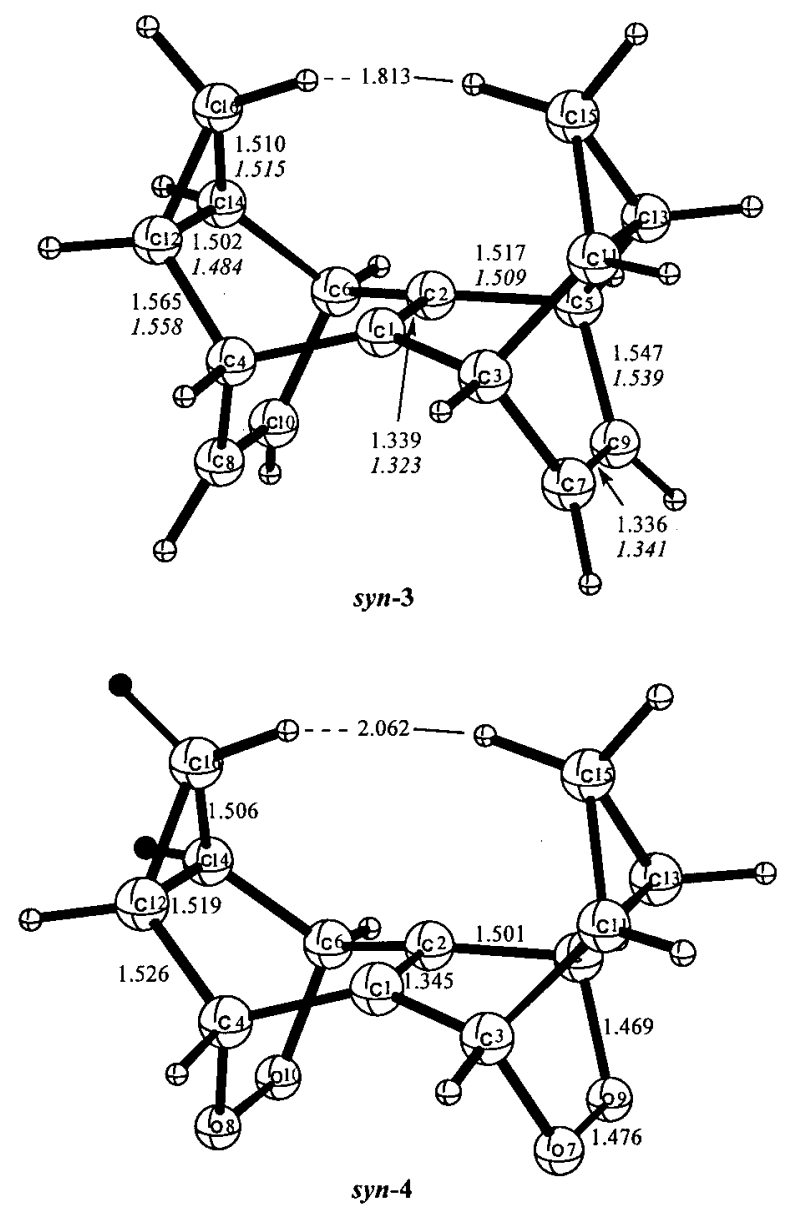

Figure 2. Calculated structures of the compounds syn-3 and syn-4.

Table 2. Theoretical and Experimental Bond Angles for syn-3 and Theoretical Bond Angles for syn-4

\begin{tabular}{cccc}
\hline & \multicolumn{2}{c}{ syn-3 } & $\begin{array}{c}\text { syn-4 } \\
\text { theory }\end{array}$ \\
\cline { 2 - 4 } & expt $^{7}$ & theory & 106.2 \\
$1-3-7$ & 105.7 & 106.0 & 113.0 \\
$1-3-11$ & 110.5 & 110.1 & 112.7 \\
$2-1-3$ & 114.7 & 114.1 & 110.4 \\
$3-7-9$ & 112.7 & 113.7 & 123.4 \\
$3-11-15$ & 123.5 & 124.2 & 105.5 \\
$7-3-11$ & 101.5 & 102.2 & 59.7 \\
$11-13-15$ & 60.8 & 60.2 & 60.5 \\
$11-15-13$ & 58.9 & 59.7 & 19.7 \\
$3-1-2-6$ & 19.9 & 16.9 &
\end{tabular}

of the central double bond. Thus, the increased bending of syn-4 is most likely not due to steric effects.

Second, orbital interactions between the peroxide system and the central double bond might play a role. NBO analysis shows that there are very few significant orbital interactions in these systems. In the carbon compound all of the larger interactions are found within the cyclopropane ring and are due to steric strain of the small ring system. In the peroxide there are four additional orbital interactions involving $\pi_{\mathrm{C} 1=\mathrm{C} 2}$ as a donor and the four $\sigma_{\mathrm{C}-\mathrm{O}}$ antibonds as acceptors. These orbital interactions weaken the $\mathrm{C} 1=\mathrm{C} 2$ bond by charge withdrawal and cause the $\mathrm{C} 1=\mathrm{C} 2$ bond to lengthen. Since a weaker double bond is more susceptible to bending, these orbital interactions might be responsible for the increased bending of syn-4.

The third factor is the rehybridization of carbon 3 and the symmetrically equivalent carbons 4-6 as stated by 
Bent's rule.22 According to Bent's rule, electronegative substituents prefer to be bound to hybrids with increased $\mathrm{p}$-character. The underlying reason is that $\mathrm{p}$-electrons are more weakly bound than s-electrons and can therefore be withdrawn more easily. Charge withdrawal of preferentially $p$-electrons causes the remaining bonds to be higher in s-character. This rehybridization is confirmed by NBO analysis. In syn-3 C3 employs an $\mathrm{sp}^{3.13}$ hybrid for bonding with $\mathrm{C} 7$, and in syn-4 C3 uses an $\mathrm{sp}^{4.66}$ hybrid for the corresponding bond with 07 . The $\mathrm{C} 3-\mathrm{C} 1$ bond is formed with $\mathrm{sp}^{2.78}$ and $\mathrm{sp}^{2.53}$ hybrids, and the C3-C11 bond involves $\mathrm{sp}^{3.18}$ and $\mathrm{sp}^{2.58}$ hybrids in syn-3 and syn4, respectively. The higher s-character employed by C3 for these bonds is consistent with the decreased distances between $\mathrm{C} 3$ and $\mathrm{C} 1$ and between $\mathrm{C} 3$ and $\mathrm{C} 11$ and with the increase of the $\mathrm{C} 1-\mathrm{C} 3-\mathrm{C} 11$ angle of $2.9^{\circ}$.

\section{Conclusion}

In summary, theoretical and experimental results are in excellent agreement and predict the peroxide compound syn-4 to be more pyramidalized than syn-3. Electronic structure analysis suggests that the increased pyramidalization in syn-4 results from two factors. Hyperconjugation between the central $\pi$-bond and the four adjacent $\mathrm{C}-\mathrm{O}$ bonds weakens the $\mathrm{C} 1=\mathrm{C} 2$ bond and causes the $\mathrm{C} 1=\mathrm{C} 2$ bond to lengthen. The weaker double bond is more susceptible to bending. Furthermore, the increased pyramidalization can be attributed to rehybridization at C3, C4, C5, and C6. The increased distance between cycl opropane hydrogens can be rationalized by the increased pyramidalization of the central double bond. The increased reactivity for these norcaradienetype endoperoxides which is probably arising from further folding of the central double bond is also in agreement with the theoretical calculations.

\section{Experimental Section}

Melting points were determined on a Thomas-Hoover capillary melting point apparatus. IR spectra were obtained from films on $\mathrm{NaCl}$ plates for liquids or $\mathrm{KBr}$ pellets for solids on a Perkin-Elmer 377 infrared recording spectrometer. ${ }^{1} \mathrm{H}$ and ${ }^{13} \mathrm{C}$ NMR spectra were recorded on a 200 (50) MHz spectrometer and are reported in $\delta$ units with $\mathrm{SiMe}_{4}$ as internal standard. All column chromatography was performed on silica gel (60 mesh, Merck) and florisil (60-100 mesh).

Photooxygenation of dimethyl trans-3,8-Dihydroheptalene-3,8-dicarboxylate (5). Dimethyl 13,14-Dioxatetracyclo[7.3.2.0.2,8 $0^{10,12}$ ]tetradeca-2(8)3,6-triene-5,11-dicarboxylate (7). Tetraphenylporphyrin $(10 \mathrm{mg})$ and diester $5(100$ $\mathrm{mg}, 0.37 \mathrm{mmol}$ ) were dissolved in $80 \mathrm{~mL}$ of $\mathrm{CCl}_{4}$. The solution was irradiated with a projection Iamp (50 W) while a slow stream of dry oxygen was passed through it continuously at $10^{\circ} \mathrm{C}$. After a total irradiation time of $2 \mathrm{~h}$, the solvent was evaporated at low temperature $\left(0-10^{\circ} \mathrm{C}\right)$. The residue was filtered through florisil $(5 \mathrm{~g})$ eluting with $\mathrm{CHCl}_{3}(100 \mathrm{~mL})$ to give endoperoxide 7 as col orless solid ( $30 \mathrm{mg}, 27 \%$ ): $\mathrm{mp} 133-$ $134{ }^{\circ} \mathrm{C}$ from $\mathrm{CHCl}_{3} /$ ether; ${ }^{1 \mathrm{H}} \mathrm{NMR}\left(200 \mathrm{MHz}, \mathrm{CDCl}_{3}\right) \delta 6.30$ (d, A part of AX system, J $=9.2 \mathrm{~Hz}, 2 \mathrm{H}$ ), 5.42 (dd, X part of AX system, $J=9.2$ and $5.5 \mathrm{~Hz}, 2 \mathrm{H}), 5.10(\mathrm{~m}, 2 \mathrm{H}), 3.85(\mathrm{~s}$, $3 \mathrm{H}), 3.65(\mathrm{~s}, 3 \mathrm{H}), 2.36-2.29(\mathrm{~m}, 3 \mathrm{H}), 0.96(\mathrm{t}, \mathrm{J}=3.1 \mathrm{~Hz}, 1 \mathrm{H})$; ${ }^{13} \mathrm{C}$ NMR $\left(50 \mathrm{MHz}, \mathrm{CDCl}_{3}\right) \delta 173.07,171.80,135.68,124.61$, $116.13,77.70,53.06,52.61,44.62,22.36,16.38$; IR $\left(\mathrm{KBr}, \mathrm{cm}^{-1}\right)$ 2950, 1730,1720,1440,1410, 1330, 1295, 1250, 1165, 1020 and 940. Anal. Calcd for $\mathrm{C}_{16} \mathrm{H}_{16} \mathrm{O}_{6}: \mathrm{C}, 63.2 ; \mathrm{H}, 5.3$. Found: $\mathrm{C}$, 63.4.; $\mathrm{H}, 5.1$.

(22) Bent, H. A. Chem. Rev. 1961, 61, 275.
Dimethyl (IaR,2R,8S,8aS)-2,8-dihydroxy-I,Ia,2,5,8,8ahexahydrocyclopropa[4,5]benzo[a]cycloheptene-1,5-dicarboxylate (10). The endoperoxide 7 ( $35 \mathrm{mg}, 0.11 \mathrm{mmol}$ ) was dissolved in $5 \mathrm{~mL}$ of $\mathrm{CHCl}_{3}$. A solution of thiourea (20 mg, $0.26 \mathrm{mmol}$ ) in $5 \mathrm{~mL}$ of methanol was added dropwise in 2-3 $\mathrm{min}$. After the solution was stirred at room temper ature for 2 $\mathrm{h}$, the solvent was evaporated. The residue was dissolved in $100 \mathrm{~mL}$ of $\mathrm{CHCl}_{3}$, washed with water $(3 \times 25 \mathrm{~mL})$, and dried over $\mathrm{MgSO}_{4}$. The reduction product $\mathbf{1 0}$ was obtained as a col orless liquid (30 mg, 85\%): ${ }^{1} \mathrm{H}$ NMR (200 MHz, $\left.\mathrm{CDCl}_{3}\right) \delta$ $6.26(\mathrm{~d}, \mathrm{~A}$ part of $\mathrm{AX}$ system, $J=8.3 \mathrm{~Hz}, 2 \mathrm{H}), 5.11(\mathrm{dd}, \mathrm{X}$ part of AX system, $J=8.3$ and $5.7 \mathrm{~Hz}, 2 \mathrm{H}), 4.56(\mathrm{~m}, 2 \mathrm{H}), 3.75(\mathrm{~s}$, $3 \mathrm{H}), 3.65(\mathrm{~s}, 3 \mathrm{H}), 2.35(\mathrm{t}, J=5.7 \mathrm{~Hz}, 1 \mathrm{H}), 2.17(\mathrm{~m}, 2 \mathrm{H}), 1.24$ $(\mathrm{t}, \mathrm{J}=3.9 \mathrm{~Hz}, 1 \mathrm{H}) ;{ }^{13} \mathrm{C} \mathrm{NMR}\left(50 \mathrm{MHz}, \mathrm{CDCl}_{3}\right) \delta 173.83,172.89$, 136.38, 128.47 (2C), 68.26, 52.96, 52.54, 40.69, 25.31, 23.11; IR $\left(\mathrm{NaCl}, \mathrm{cm}^{-1}\right) 3400,3020,2950,1720,1720,1435,1285$, and 975. Anal. Calcd for $\mathrm{C}_{16} \mathrm{H}_{18} \mathrm{O}_{6}$ : C, 62.7; H, 5.9. Found: $\mathrm{C}, 62.2$; $\mathrm{H}, 6.1$.

Oxidation of Diol 10. exo-Dimethyl 2,7-Dioxo-1a,2,7,7a-tetrahydro-1H-cyclopropa[b]naphthalene-1,4-dicarboxylate (11). Freshly prepared active $\mathrm{MnO}_{2}(\mathrm{~g}, 72 \mathrm{mmol})$ was added to a solution of $\mathbf{1 0}(100 \mathrm{mg}, 0.32 \mathrm{mmol}$ ) in $20 \mathrm{~mL}$ of $\mathrm{CHCl}_{3}$ at room temperature. The reaction mixture was stirred at room temperature for 7 days. The precipitate was filtered out and washed with $\mathrm{CHCl}_{3}$. The combined organic layers were evaporated to give colorless crystals (30 mg, 32\%, mp 85-86 $\left.{ }^{\circ} \mathrm{C}\right)$ from ether: ${ }^{1} \mathrm{H}$ NMR $\left(200 \mathrm{MHz}, \mathrm{CDCl}_{3}\right) \delta 8.65(\mathrm{~d}, \mathrm{~J}=1.5$ $\mathrm{Hz}, 1 \mathrm{H}), 8.39$ (dd, A part of AX system, $\mathrm{J}=8.0$ and $1.5 \mathrm{~Hz}$, $1 \mathrm{H}), 8.08(\mathrm{~d}, \mathrm{X}$ part of AX system, $\mathrm{J}=8.0,1 \mathrm{H}), 3.90(\mathrm{~s}, 3 \mathrm{H})$, $3.70(\mathrm{~s}, 3 \mathrm{H}), 3.19(\mathrm{~d}, \mathrm{~J}=4.4,2 \mathrm{H}), 2.65(\mathrm{t}, \mathrm{J}=4.4,1 \mathrm{H}) ;{ }^{13} \mathrm{C}$ NMR $\left(50 \mathrm{MHz}, \mathrm{CDCl}_{3}\right) \delta 189.82,189.57,168.81,165.54$, $136.22,135.40,135.22,132.72,129.09,128.05,53.44,53.24$, 34.35 (2C), 31.42; IR ( $\left.\mathrm{KBr}, \mathrm{Cm}^{-1}\right)$ 3050, 2940, 1725, 1680,1600, 1440, 1310, 1280, 1200, and 960. Anal. Calcd for $\mathrm{C}_{15} \mathrm{H}_{12} \mathrm{O}_{6}$ : C, 62.5; H, 4.4. Found: C, 62.1; H, 4.4.

Photooxygenation of 5 with 2 mol of ${ }^{1} \mathrm{O}_{2}$. exo,exoDimethyl 13,14,15,16-Tetraoxahexacyclo[7.3.2.2 $2^{3,7} \cdot 0^{2,8}$ $.0^{4,6} 0^{10,12}$ ] hexadec-2(8)-ene-5,11-dicarboxylate (syn-4). Tetraphenyl porphyrin $(10 \mathrm{mg})$ and diester $\mathbf{5}(100 \mathrm{mg}, 0.37 \mathrm{mmol})$ were dissolved in $75 \mathrm{~mL}$ of $\mathrm{CCl}_{4}$. The solution was irradiated with a projection lamp $(50 \mathrm{~W})$ while a slow stream of dry oxygen was passed through it continuously at $0{ }^{\circ} \mathrm{C}$. After a total irradiation time of $24 \mathrm{~h}$, the solvent was evaporated at low temperature $\left(0-10^{\circ} \mathrm{C}\right)$. Crystallization of the residue from $\mathrm{CH}_{2} \mathrm{Cl}_{2} /$ ether yiel ded bis(norcaradiene) bis(endoperoxide) syn-4 as a colorless powder (15 mg, $20 \%$ ), dec $117-119^{\circ} \mathrm{C}:{ }^{1 \mathrm{H}} \mathrm{NMR}$ $\left(200 \mathrm{MHz} \mathrm{CDCl}_{3}\right) \delta 5.18(\mathrm{~m}, 4 \mathrm{H}), 3.71(\mathrm{~s}, 3 \mathrm{H}), 2.33(\mathrm{~m}, 4 \mathrm{H})$, $1.44(\mathrm{t}, \mathrm{J}=3.2 \mathrm{~Hz}, 2 \mathrm{H}) ;{ }^{13} \mathrm{C} \mathrm{NMR}\left(50 \mathrm{MHz}^{2} \mathrm{CDCl}_{3}\right) \delta 171.23$, 135.48, 75.18, 52.88, 22.16, 16.43; IR $\left(\mathrm{KBr}, \mathrm{cm}^{-1}\right)$ 3040, 3000, 2950, 1715, 1435, 1330, 1250, 1160, 940, and 925.

Rearrangement of 4 at Room Temperature. exo,exoDimethyl (1R,2R,4S,5S,7R, 8R,I0S,11S,12S,14R)-3,9,15,16-

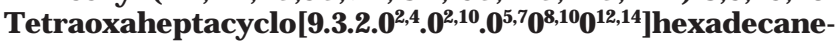
6,13-dicarboxylate (16). A solution of bis(norcaradiene) bis(endoperoxide) syn-4 $(25 \mathrm{mg}, 0.07 \mathrm{mmol})$ in $\mathrm{CHCl}_{3}(10 \mathrm{~mL})$ was stirred at room temperature for 5 days. The rearrange ment of the bis(endoperoxide) syn-4 to $\mathbf{1 6}$ was monitored by ${ }^{1} \mathrm{H}$ NMR spectroscopy. ${ }^{1} \mathrm{H}$ NMR analysis indicated that bis(epoxy) endoperoxide $\mathbf{1 6}$ was formed quantitatively. Crystallization from $\mathrm{CHCl}_{3} /$ ether gave $\mathbf{1 6}$ (isolated yield 63\%), dec 170 ${ }^{\circ} \mathrm{C}$ : ${ }^{1} \mathrm{H}$ NMR $\left(200 \mathrm{MHz} \mathrm{CDCl}_{3}\right) \delta 4.21(\mathrm{~m}, 2 \mathrm{H}), 3.77(\mathrm{~s}, 3 \mathrm{H})$, $3.76(\mathrm{~s}, 3 \mathrm{H}), 3.39(\mathrm{br} \mathrm{s}, 2 \mathrm{H}), 2.42(\mathrm{~m}, 2 \mathrm{H}), 2.13$ (br d, A part of $\mathrm{A}_{2} \mathrm{~B}$ system, J $=4.3 \mathrm{~Hz}, 2 \mathrm{H}$ ), 2.05 (t, B part of $\mathrm{A}_{2} \mathrm{~B}$ system, J $=4.3,1 \mathrm{H}), 1.64(\mathrm{t}, \mathrm{J}=2.2 \mathrm{~Hz}, 1 \mathrm{H}) ;{ }^{13} \mathrm{C} \mathrm{NMR}\left(50 \mathrm{MHzCDCl}_{3}\right)$ $\delta 171.31,170.73,57.43,53.03,52.94,50.77$ (2C), 21.64, 21.46, 20.28 (2C); IR ( $\left.\mathrm{KBr}, \mathrm{Cm}^{-1}\right) 3000,2940,1720,1715,1445,1310$, 1170, and 1020. Anal. Calcd for $\mathrm{C}_{16} \mathrm{H}_{18} \mathrm{O}_{8}:$ C, 57.1; $\mathrm{H}, 4.8$. Found: $57.5 ; \mathrm{H}, 4.6$.

Photooxgenation of $17^{\mathrm{e} e}$ and Conversion of Endoperoxide 18 into Bis(epoxide) 19. Tetraphenyl porphyrin (10 $\mathrm{mg}$ ) and compound $\mathbf{1 7}(280 \mathrm{mg}, 0.74 \mathrm{mmol}$ ) were dissolved in $30 \mathrm{~mL}$ of $\mathrm{CHCl}_{3}$. The solution was irradiated with a projection lamp (50 W) while a slow stream of dry oxygen was passed through it continuously at $10^{\circ} \mathrm{C}$. After a total irradiation time of $3.5 \mathrm{~h}$, the solvent was evaporated at low temperature (0- 
6676 J . Org. Chem., Vol. 64, No. 18, 1999

$\left.10^{\circ} \mathrm{C}\right) .{ }^{1} \mathrm{H} N \mathrm{NM}$ analysis of the residue indicated the formation of the expected endoperoxide $\mathbf{1 8}$ in quantitative yield which was unstable at room temperature.

Dimethyl (1R,3R,4R,6S,7S,9S,10S,15R,16R,18S)-11,14Dioxo-19,20-dioxahexacyclo[7.6.3.2 $\left.2^{3,7} 0^{2,8} 0^{10,15} 0^{16,18}\right]$ icosa2(8),12-diene-5,17-dicarboxylate (18). Data: ${ }^{1} \mathrm{H}$ NMR (200 $\left.\mathrm{MHz} \mathrm{CDCl}_{3}\right) \delta 6.51(\mathrm{~s}, 2 \mathrm{H}), 4.66(\mathrm{~m}, 2 \mathrm{H}), 3.83(\mathrm{~m}, 2 \mathrm{H}), 3.63(\mathrm{~s}$, $3 \mathrm{H}), 3.62(\mathrm{~s}, 3 \mathrm{H}), 3.06(\mathrm{~m}, 2 \mathrm{H}), 2.06(\mathrm{~m}, 4 \mathrm{H}), 1.91(\mathrm{~m}, 2 \mathrm{H})$, 1.78 (br. t, $1 \mathrm{H}), 1.31(\mathrm{t}, \mathrm{J}=2.9 \mathrm{~Hz}, 1 \mathrm{H}) ;{ }^{13} \mathrm{C} \mathrm{NMR}(50 \mathrm{MHz}$ $\left.\mathrm{CDCl}_{3}\right) \delta 197.30,172.93,171.53,141.28,136.58,75.73,52.69$, $52.60,50.27,37.58,22.13,21.93,18.89$. The endoperoxide 18 was unstable and rearranged at room temperature to the corresponding bis(epoxide) $\mathbf{1 9}$ in $\mathbf{8}$ days in quantitative yield. Crystallization from $\mathrm{CHCl}_{3} /$ ether yielded 19 (isolated yield 72\%) as a colorless solid, $\mathrm{mp} 229-231{ }^{\circ} \mathrm{C}$.

Dimethyl (1R,2R,4S,5S,7R,8R,10S,11S,12S,17R,18R,20S)-3,9-Dioxa-13,16-dioxoheptacyclo[9.6.3.02,4.02,10
Saraçoğlu et al.

$\left..0^{5,7} .0^{8,10}, 0^{12,17} \cdot 0^{18,20}\right]$ icos-14-ene-6,19-dicarboxylate (19). Data: ${ }^{1} \mathrm{H}$ NMR $\left(200 \mathrm{MHz} \mathrm{CDCl}_{3}\right) \delta 6.88(\mathrm{~s}, 2 \mathrm{H}), 3.75(\mathrm{~s}, 3 \mathrm{H})$, $3.72(\mathrm{~s}, 3 \mathrm{H}), 3.25(\mathrm{br} \mathrm{s}, 2 \mathrm{H}), 3.20(\mathrm{~m}, 2 \mathrm{H}), 2.59(\mathrm{~m}, 2 \mathrm{H}), 2.08-$ $1.98(\mathrm{~m}, 3 \mathrm{H}), 1.94(\mathrm{~m}, 2 \mathrm{H}), 1.61(\mathrm{t}, \mathrm{J}=3.1 \mathrm{~Hz}, 1 \mathrm{H}) ;{ }^{13} \mathrm{C} \mathrm{NMR}$ $\left(50 \mathrm{MHzCDCl}_{3}\right) \delta 197.36,171.99,171.45,141.38,58.47,52.86$, 52.82, 50.27, 46.08, 40.41, 22.43, 21.99, 21.74, 19.27; IR (KBr, $\mathrm{cm}^{-1}$ ) 3030, 3000, 2950,1730,1665,1505,1490, 1310, 1285, 1165, 970, and 950. Anal. Calcd for $\mathrm{C}_{22} \mathrm{H}_{20} \mathrm{O}_{8}$ : C, 64.1; H, 4.9. Found: $\mathrm{C}, 63.8$.; $\mathrm{H}, 4.7$.

Acknowledgment. The authors are indebted to the Departments of Chemistry (Atatürk University and Middle East Technical University) for financial support of this work and the State Planning Organization of Turkey (DPT) for purchasinga200M HzNMR spectrometer.

J 09903930 